\title{
Subject Diffuseness in Maltese: \\ On Some Subject Properties of Experiential Verbs"
}

\author{
Martin Haspelmath \& Sandro Caruana
}

\begin{abstract}
Like many other languages, Maltese shows some peculiarities in the behavior of its experiential verbs. While the case-marking and agreement properties of these verbs point to (direct or indirect) object status of the experiencer argument, several behavioral properties make the experiencer argument appear more similar to subjects. Different sub-types of experiential verbs can be distinguished, and a number of individual verbs (most notably the possessive verb ghandu/kellu 'have', well-known from the earlier literature) show further peculiarities. The various groups of verbs or individual verbs can be arranged on a continuum which shows an increasing number of subject properties of the experiencer (or possessor) argument. Thus, subject properties are not distributed in a clear-cut manner, and we observe a certain amount of "subject diffuseness".
\end{abstract}

\section{Experiential verbs in Maltese}

\subsection{Subject diffuseness}

Comrie \& Borg (1984) have drawn attention to some problems in identifying objects with certain transitive verbs in Maltese, and they concluded that the category of object is not always clear-cut, but that we find a certain "object diffuseness". In this paper, we observe the same with respect to the category of subject: Especially experiential verbs in Maltese (i.e. verbs with an experiencer argument and a stimulus argument) force us to recognize a certain "subject diffuseness". Experiential verbs from two classes and a few other verbs show peculiar behavior in that their experiencer argument behaves like a prototypical subject (e.g. a subject of a transitive action sentence) in some respects, but like a non-subject in others. For instance, in (1) the NP it-tifla 'the girl' has some subject properties (such as preverbal position), but lacks others (such as ordinary subject-verb agreement). ${ }^{1}$ 
(1) It-tifla jiddispjaciha ghall-iżball.

the-girl regret.IP.her for.the-mistake

'The girl regrets the mistake.'

This phenomenon is not unexpected, because many other languages show related peculiarities in the syntactic behavior of experiential verbs. However, as far as we know it has not been described in any detail for Maltese or any other closely related language so far.

Our description will be primarily synchronic. However, since there appears to be a widespread trend in the diachronic development of experiential verbs, namely the gradual acquisition of an increasing number of subject properties by the experiencer argument (cf. Cole et al. 1980), it will be helpful to adopt a diachronic perspective occasionally. Since this change involves the stepwise transfer of the subject status from the stimulus to the experiencer argument, the term "subject" is potentially misleading, and we will try to make the meaning of this term clear by speaking of the "original subject" and the "new subject".

There is an enormous literature devoted to the question of the most elegant formal description of experiential verbs (e.g. Belletti \& Rizzi 1988 for Italian, Pesetsky 1995 for English) or to the explanation of these peculiarities (e.g. Croft 1993). There is also a substantial amount of cross-linguistic work on experiential verbs, e.g. Bossong's (1998) survey of 40 European languages, Reh (1998) on African languages, as well as the papers in Aikhenvald et al. (2001). It is not our intention here to use the Maltese data to confirm or refute a particular formal descriptive framework, or to situate Maltese in a broader typological context. Besides our descriptive goal, the main theoretical point of this paper is that the Maltese data show a continuum of subjecthood with a number of predicate types that are not prototypical transitive verbs. To our knowledge, this particular point has not been made before (although of course the idea that there are prototypical and less prototypical subjects is present already in Keenan's 1976 influential article).

\subsection{Maltese experiential verbs}

Experiential verbs can be grouped into three classes in Maltese: First, experiential verbs may show an unequivocal subject experiencer, e.g. habb 'love', $r a$ 'see' (e.g. jien rajt il-ballun 'I saw the ball'). These behave like normal transitive verbs in every respect and show no special behavior, so they will not be discussed any further in this paper. It is difficult to characterize this class in positive terms because it is not easily delimited from transitive non-experiential verbs. The two other classes will be the focus of our interest here: (i) those in which the stimulus appears as the original subject and the experiencer is marked as accusative (which we will call TRANSITIVE EXPERIENTIAL VERBS), and (ii) those in which neither the experiencer nor the stimulus is originally a subject 
argument (which we will call IMPERSONAL EXPERIENTIAL VERBS). While the first group forms a substantial and essentially open-ended class (cf. 2a), for the second group we have found only four verbs so far (cf. 2b).

(2) a. Transitive experiential verbs

$\begin{array}{ll}\text { inkwieta } & \text { 'worry' } \\ \text { issorprenda } & \text { 'surprise' } \\ \text { ghaggeb } & \text { 'surprise' } \\ \text { interessa } & \text { 'interest' } \\ \text { gh ogob } & \text { 'please (=like)' } \\ \text { iddisgusta } & \text { 'disgust' } \\ \text { qażżėz } & \text { 'disgust' }\end{array}$

b. Impersonal experiential verbs

$\begin{array}{ll}\text { iddispjacih } & \text { 'regret' } \\ \text { jisgh obbih } & \text { 'regret, feel pity for' } \\ \text { irnexxielu } & \text { 'manage' } \\ \text { fettillu } & \text { 'happen to' }\end{array}$

In addition to discussing experiential verbs, we will review the behavior of ghandu/kellu 'have', which also presents some intriguing peculiarities. Since the diachronic development of an original non-subject argument to subject status can be illustrated nicely with this verb, we will start our discussion here.

The special behavior of the verb ghandu/kellu ${ }^{2}$ 'have' in Maltese is wellknown from the work of Comrie (1982, 1989:219-224). The present tense of this verb developed diachronically from the preposition $g$ hand 'at' by a gradual change in which a hypothetical source construction such as (3a), involving topicalization and left dislocation of the location NP Maria with a resumptive pronoun on the locative preposition, ${ }^{3}$ turned into (3b). This is a typical instance of a grammaticalization from topic to subject.

(3) a. Maria, ghand-ha baqra.

Maria at-3sG.F cow

'Maria, there is a cow at her place.'

b. Maria ghand-ha baqra.

Maria have-3SG.SUBJ cow

'Maria has a cow.'

Comrie adduces a number of arguments to show that syntactically, ghandu indeed has verb status in contemporary Maltese, although it still behaves like a preposition morphologically - i.e. the subject agreement affixes have the shape and position of prepositional argument affixes, not of ordinary verbs. In particular, ghandu is negated by the discontinuous negative marker ma... -x, just like verbs, but unlike non-verbal predications. Thus, $(3 b)$ behaves in many ways like a normal transitive verbal clause, quite unlike its diachronic source (3a). 
(Stassen 2001 notes that this type of change is not uncommon crosslinguistically, and he calls it "have-drift".)

It is plausible to assume that a similar change is taking place in the case of the experiential verbs in (2). The preverbal experiencer it-tifla in (1) was originally a left-dislocated direct object, as can still be seen in the object-agreement marker $-h$ in the verb form jiddispjaciha, which cross-references the experiencer argument. The sentence (1) therefore originally had the literal translation 'The girl, it regrets her for the mistake'. We will show, however, that the experiencer has not yet acquired as many subject properties as the verb ghandu/kellu. Of course, the additional change from prepositional status to verbal status was not necessary in our cases, because the experiential verbs have always been verbs.

Thus, we will focus on subject properties (i.e. properties of subjects not shared by nonsubjects) of the experiencer (or possessor) argument. Comrie already noticed two salient subject properties that the possessor of ghandu/kellu has: (i) It occurs in preverbal position, and (ii) it is obligatorily zero-marked. In the following, we will look at five further subject properties which are characteristic of prototypical subjects in Maltese: (iii) agreement with the verb is obligatory; (iv) the subject is raisable in raising constructions with ried 'want'; (v) 'want' complements allow complementizer drop when the complement subject is coreferential with the 'want' subject; (vi) subjects may be imperative addressees; (vii) subjects may control reflexive pronouns. But before we turn to our main topic, some background information on Maltese morphology and syntax will be given.

\subsection{Some morphosyntactic properties of Maltese}

Maltese is a Semitic language closely related to Arabic - in fact, it can be thought of as descending from Classical Arabic much in the same way as the modern Arabic vernaculars, with which it shares many features. It is a largely head-initial SVO language with a moderate amount of inflection: Nouns inflect for number, definiteness (prefixed definite article $i l$-, with morphophonemic variants), and (inalienable nouns only) person-number-gender of the possessor; adjectives inflect for number, gender, and definiteness; and verbs inflect for aspect and person-number-gender of their core arguments (subject, direct object, indirect object).

Subject person-number-gender inflection is to a large extent cumulated with inflection for aspect. There are two aspects: Perfect (often with a past-tense interpretation) and Imperfect (often with a present-tense interpretation). In (4), we give sample paradigms for the verb fetah 'open' (cf. Borg \& AzzopardiAlexander 1997:358-382 for details). ${ }^{4}$ As these paradigms show, Maltese verbs show extensive vowel alternations, as is typical of Semitic languages. 
(4) a. Perfect with subject inflection b. Imperfect with subject inflection

$\begin{array}{ll}\text { SG } 1 \text { ftah-t 'I opened', etc. } & \text { ni-ftah 'I am opening', etc. } \\ 2 \text { ftah-t } & \text { ti-ftah } \\ \text { 3M fetah } & \text { ji-ftah } \\ 3 \text { F feth-et } & \text { ti-ftah } \\ \text { PL } 1 \text { ftah-na } & \text { ni-fth-u } \\ 2 \text { ftah-tu } & \text { ti-fth-u } \\ 3 \text { feth-u } & \text { ji-fth-u }\end{array}$

Thus, subject inflection is suffixing in the Perfect, and prefixing-suffixing in the Imperfect. Object inflection is always purely suffixing. As (5) shows, object inflection uses a different set of suffixes, almost identical to the possessor suffixes on inalienable nouns. ${ }^{5}$ Indirect-object inflection contains an additional marker $l$.

$\begin{array}{ll}\text { a. Possessor infl. } & \text { b. Direct-object infl. } \\ \text { SG 1 dar-i } & \text { feuh-ni } \\ 2 \text { dar-ek } & \text { fethu-k } \\ \text { 3M dar-u } & \text { fethu-h } \\ \text { 3F dar-ha } & \text { fethu-ha } \\ \text { PL 1 dar-na } & \text { fethu-na } \\ 2 \text { dar-kom } & \text { fethu-kom } \\ 3 \text { dar-hom } & \text { fethu-hom }\end{array}$
c. Indirect-object infl. fethu-li fethu-lek feth u-lu fethu-lha fethu-lna fethu-lkom fethu-lhom

Prepositions and some other words (e.g. innifs- 'self') take these personnumber-gender suffixes as well. Since the focus in this paper will be on syntax, our interlinear glosses will be simplified and will not show the morphological segmentation. Thus, the form qabditni 'she caught me' will not be glossed fully as qabd-it-ni [catch.PF-3SG.SUBJ-1SG.OBJ], but simply as qabditni [she.catch.PF.me].

Like the modern Arabic vernaculars, Maltese has completely lost the old case-marking suffixes. However, direct objects are often marked by the preposition lill'illl- (originally 'to', and still glossed as 'to' in our examples), especially when they are animate and definite. This preposition can be regarded as a new case-marker (e.g. Jien rajt lil Mario 'I saw Mario').

\section{Subject properties of the experiencer of $g$ handu/kellu 'have'}

We begin by examining the behavior of ghandu/kellu with respect to the subject properties mentioned in $\$ 1.2$, and we will contrast this verb with the experiential verbs later on.

\subsection{Raising}

The verb ried 'want' allows two different ways of forming its complement when its subject and the complement subject are disjoint: The complement may 
be an ordinary complement clause introduced by the all-purpose complementizer $l i$, or it may occur in a raising construction in which the complement subject is raised to the direct-object position of 'want' (much like in the English construction), and the complementizer is omitted. This is illustrated for the standard transitive verb $h a b b$ 'love' in (6).
a. Irrid li thobb l-ghalliem il-gdid.
I.want.IP that you.love.IP the-teacher the-new
'(lit.) I want that you love the new teacher.'
b. Irridek thobb l-ghalliem il-gdid.
I.want.IP.you you.love.IP the-teacher the-new
'I want you to love the new teacher.'

With the verb ghandu, however, the raising construction is not possible: ${ }^{6}$
(7)
a. Irrid li jkollok il-ktieb.
I.want.IP that you.have.sBJV the-book
'(lit.) I want that you have the book.'
b. *Irridek ikollok il-ktieb.
I.want.IP.you you.have.SBJV the-book
'I want you to have the book.'

Thus, in this respect the 'have' experiencer does not behave like a prototypical subject yet. However, with respect to the other subject properties, the 'have' experiencer is indistinguishable from prototypical subjects, as we will see in the next subsections.

\subsection{Complementizer drop in 'want' complements}

In same-subject complements of the verb ried 'want', the complementizer $l i$ can optionally be omitted, as shown in (8a). (In different-subject complements, omission of $l i$ is not possible (cf. 6a), unless the raising construction is used (cf. 6b).) This complementizer omission is also possible with ghandu/kellu 'have', cf. (8b). ${ }^{7}$
(8)
a. It-tifel irid
(li) jigi
d-dar kmieni.
the-boy he.want.IP that he.come.IP the-house early
'The boy wants to come home early.'
b. It-tifla trid
(li) jkollha
ballun.
the-girl she.want.IP (that) she.have.sBJv ball
'The girl wants to have a ball.'

\subsection{Imperative addressee}

The verb ghandu/kellu may occur in the imperative, with the experiencer/possessor as the addressee: 
(9) Ikollok hniena minna.

you.have.IMPV mercy from.us

'Have mercy upon us.'

However, one might doubt that this is a real imperative - it could perhaps also be regarded as a main-clause subjunctive form (cf. fn. 5 on the notion of subjunctive in Maltese). It certainly differs from the other imperatives in that the morphological marker of the imperative subject is not omitted from the morphological form (cf. hobb 'love!', contrasting with thobb 'you love'). A hypothetical form such as $* i k o l l$ (lacking the 2 nd person suffix $-o k$ ) is completely impossible in Maltese (but this might be regarded as a purely morphological constraint).

Thus, until we come up with precise syntactic criteria for delimiting imperatives from main-clause subjunctives, this criterion, too, is not entirely conclusive.

\subsection{Reflexive control}

The reflexive pronoun in Maltese is formed by a personal pronoun followed by the intensifier innifs- ('self'). Thus, we have constructions such as (10).

(10) Inhobb lili nnifsi.

I.love.IP to.me my.self

'I love myself.'

An experiencer that lacks other subject properties (e.g. the experiencer in the transitive experiential verb ghogob 'please') also lacks the ability to control reflexives, as we see in (11), which is not just ungrammatical, but incomprehensible, like its English counterparts 'She-self pleases Lisa'.

(11) *Hija nnifisha toghgob 'il Lisa.

she her.self she.please.IP to Lisa

'She-self pleases Lisa', i.e. 'Lisa likes herself.'

Preposing the experiencer into a preverbal topic position does not help:

(12) *(Lil) Lisa toghgobha hija nnifisha.

to Lisa she.please.IP.her she her.self

'Lisa, she-self pleases her', i.e. 'Lisa likes herself.'

No such problem exists with ghandu/kellu:

(13) Lisa ghandha lilha nnifisha.

Lisa she.have.IP to.her her.self

'Lisa has herself.' 


\section{Impersonal experiential verbs}

In this section we present the evidence for a similar tendency to grammaticalize the experiencer argument in the experiential verbs listed in (2) above. This tendency is strongest with the impersonal verbs, which in the original construction lack a subject. These are originally analogous to Latin verbs such as taedet $m e_{\mathrm{ACC}}$ alicujus re $i_{\mathrm{GEN}}$ 'something disgusts me', or Old English verbs such as

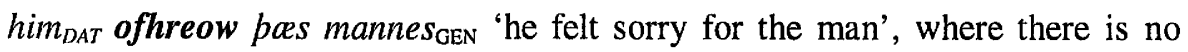
nominative argument.

The four verbs occur in three different constructions:

(i) With iddispjacih, we have an original direct-object experiencer (as can be seen from the agreement affixes on the verb, which are just like direct-object affixes), ${ }^{8}$ and the stimulus is marked by the preposition $g h a l$ 'for', as shown in (14). ${ }^{9}$

(14) Jiddispjacini ghall-iżball.

displease.IP.me for.the-mistake

'I regret the mistake.' (Originally: 'It regrets me for the mistake.')

(ii) With irnexxielu and fettillu, we have an original indirect-object experiencer (glossed here with 'to'), as can be seen from the argument suffixes (e.g. -l-ha, $-l-u$ ) incorporating an $l-$ ('to'). ${ }^{10}$ The other argument in these verbs is constituted by a complementizerless subordinate clause, e.g.

(15) Irnexxielha titfa' il-ballun fuq ić-cint.

succeed.PF.to.her [she.throw.IP the-ball over the-fence]

'She managed to throw the ball over the fence.'

(16) Fettillu jmur jara lil Mary.

happen.PF.to.him [he.go.IP he.see.IP to Mary]

'He happened to go to visit Mary.'

(iii) In the verb jisghobbih 'regret', the experiencer was originally coded by the preposition $b(i)$ 'by, with, at'. This preposition has now fused with the verb stem (originally jisghob), so that synchronically the pronominal suffixes look like direct-object suffixes, and jisghobbih is very similar to iddispjacih. ${ }^{11}$ Like this latter verb, its stimulus argument is marked by the preposition $g$ hal:

It-tfal jisghobbihom ghal dak li ghamlu.
the-children displease.IP.them for that which they.do.PF
'The children regret what they have done.'

The distinction between original direct-object, indirect-object and prepositionalobject experiencers has now become purely one of verbal agreement morphology - syntactically, the experiencer argument seems to behave in exactly the same way in these four verbs, so that they can be treated together. 


\subsection{Obligatory verb agreement}

If the direct/indirect-object suffixes in these verbs indicated normal direct or indirect objects (or even prepositional objects), as with other verbs, we would expect the verbs to be able to occur without these suffixes if an overt NP is present in the sentence. Unlike subject-verb agreement, direct-object-verb agreement and indirect-object-verb agreement is not obligatory in Maltese (cf. Fabri 1993: Ch. 5). Thus, on the analogy of (18a-b), we should have alternations such as (19)-(20)(a-b).

(18) a. It-tabib qallu biex jiehu l-medicina. the-doctor he.tell.PF.to.him so.that he.take.IP the-medicine 'The doctor told him to take the medicine.'

b. It-tabib qal lit-tifel biex jiehu l-medicina. the-doctor he.tell.PF to.the-child so.that he.take.IP the-medicine 'The doctor told the child to take the medicine.'

However, the (b) sentences of (19)-(20), where the experiential verbs lack the object suffix, are completely impossible. ${ }^{12}$

(19) a. Irnexxielhom jitfghu l-ballun.

succeed.PF.to.them they.throw.IP the-ball

'They managed to throw the ball.'

b. *Irnexxa lit-tfal jitfghu l-ballun. succeed.PF to.the-children they.throw.IP the-ball

'The children managed to throw the ball.'

(20) a. Jiddispjaciha ghall-iżball.

regret.IP.her for.the-mistake

'She regrets her mistake.'

b. *Jiddispjaċi lil Maria ghall-iżball.

regret.IP to Maria for.the-mistake

'Maria regrets her mistake.'

And if jisghobbih were still segmentable and the experiencer were a prepositional object marked by the preposition $b(i),(21 \mathrm{~b})$ should be possible. Again, (21b) is completely impossible, as is (21c).

(21) a. Jisghobbiha ghall-iżball. regret.IP.her for.the-mistake

'She regrets her mistake.'

b. *Jisghob b' Maria ghall-iżball. regret.IP to Maria for.the-mistake

'Maria regrets her mistake.'

c. *Jisghobbi lil Maria ghall-iżball. regret.IP.her to Maria for.the-mistake

'Maria regrets her mistake.' 
Thus, although the verbal suffixes that cross-reference the experiencer argument have the same shapes as direct- and indirect-object suffixes, syntactically they behave like subject agreement affixes, in that they can never be dropped. This is the first criterion with respect to which impersonal experiential verbs (analogous to ghandu/kellu) behave like personal verbs, and their experiencer behaves like a subject.

\subsection{Preverbal position}

In Maltese, subjects normally precede the verb (cf. Fabri 1993:Ch. 5 for some discussion of Maltese clause-level word order). Postverbal position of the subject is also possible, but sentences with such a word order are quite unusual (this is indicated by the single question mark in (22a-d)). The same is true for the experiencer argument of $g$ handu/kellu and of the impersonal experiential verbs:

(22) a. ?Ghandu Pawlu l-ktieb.

at.him Pawlu the-book

'Pawlu has the book.'

b. ?Jiddispjacilh (1)ir-ragel li ma xtarax il-ktieb. regret.IP.him (to.)the-man that NEG he.buy.PF.NEG the-book

'The man regrets that he didn't buy the book.'

c. ?Irnexxielha (l)it-tifla titfa' il-ballun. succeed.PF.to.her (to.)the-girl she.throw.IP the-ball 'The girl managed to throw the ball.'
d. ?Fettillu
(1)ir-ragel imur jara lil Mary. happen.PF.to.him (to.)the-man he.go.IP he.see.IP to Mary 'The man happened to go to visit Mary.'

Thus, in this respect the experiencer of impersonal verbs behaves like a subject, not like a direct or indirect object.

\subsection{Case marking}

While standard subjects in Maltese are not case-marked (or zero case-marked), the experiencer argument of impersonal verbs may be case-marked by the preposition lil (as mentioned in §1.3). However, this is not obligatory. We have not investigated whether there are any significant differences between the versions of (23) with and without lil. (Note that lil is often reduced to ' $i l$, and merges with the definite article $i l-/ i C$-, yielding the forms $l i l l-/ l i C$-.)

(23) a. (L)ir-ragel jiddispjaciih ghall-iżball.

(to.)the-man regret.IP.him for.the-mistake

'The man regrets the mistake.'

b. (L)it-tifla rnexxielha titfa' il-ballun.

(to.)the-girl succeed.PF.to.her she.throw.IP the-ball

'The girl managed to throw the ball.' 
It is not clear whether there is a syntactic difference between the two constructions, or whether this is purely a difference of case-marking, which is optional in these cases. If one wanted to claim that the syntax of these constructions is still much like that of left-dislocation of non-experiential verbs, one could take the case-marking patterns as confirming evidence, because left-dislocated constructions show the same variation of case-marking:

(24) Lill/il-halliel qabditu l-pulizija.

to.the/the-thief she.catch.PF.him the-police

'(lit.) The thief, the police caught him.'

However, when the preposed argument is a personal pronoun, case-marking is obligatory with direct and indirect objects in left-dislocation constructions:
a. LILI/*JENA qabditni she.catch.PF.me the-police to.me/I 1-pulizija.
' (lit.) Me, the police caught (me).'
b. LILI/*JIENA fethuli l-bieb.
to.me/I they.open.PF.to.me the door
'For me, they opened the door (for me).'

By contrast, with experiential verbs accusative case-marking is only optional:
(26) a. JIENA/LILI fettilli
mmur nara lin-nanna.
I/to.me happen.PF.to.me I.go.IP I.see.IP to.the-granny
'I [stressed] happened to go to visit granny.'
b. JIENA/LILI jisthoqqli t-tifhir.
I/to.me deserve.IP.to.me the-praise
'I [stressed] deserve praise.'

In some verbs, there even seems to be a clear preference for the non-casemarked form:
(27) JIENA / ??LILI rnexxieli
nitfa' il-ballun.
I to.me succeed.PF.to.me I.throw.IP the-ball
'I [stressed] managed to throw the ball.'

Thus, full-NP experiencers of impersonal verbs show mixed behavior with respect to the criterion of case marking, but when personal pronouns are examined, they behave clearly differently from direct and indirect objects.

\subsection{Raising}

As with ghandu/kellu 'have', raising is not possible with impersonal verbs (cf. 28 ). This is of course exactly what we expect. 
(28) a. Irrid li jiddispjaċik ghall-iżball.

I.want.IP that regret.IP.you for.the-mistake

'I want you to regret the mistake.'

b. *Irridek jiddispjacik ghall-iżball.

I.want.IP.you regret.IP.you for.the-mistake

'I want you to regret the mistake.'

\subsection{Complementizer drop in 'want' complements}

In $\S 2.2$ we saw that the complementizer $l i$ can be omitted in same-subject complements of ried 'want'. The experiencer of impersonal verbs does not count as a subject for this construction. In this respect, impersonal verbs contrast with ghandu/kellu.

(29) a. Lisa trid $\quad \mathrm{li} / * \varnothing \quad$ jiddispjaciha.

Lisa she.want.IP that/ $\varnothing$ regret.IP.her

'Lisa wants to regret it.'

b. Lisa trid $\quad \mathrm{li} / * \varnothing$ jirnexxielha.

Lisa she.want.IP that/Ø succeed.IP.to.her

'Lisa wants to succeed.'

\subsection{Imperative addressee}

The experiencer of impersonal verbs cannot be the subject of an imperative:

(30) *Iddispjacik ta' l-iżball!

regret.IMPV.you of the-mistake

'Regret the mistake!'

However, it might be that this is excluded for semantic reasons (cf. the strangeness of the imperative with regret in English).

\subsection{Reflexive control}

The experiencer argument of the verbs jiddispjacih and jisghobbih can control a reflexive pronoun and behaves like a subject in this respect:

(31) Mario jiddispjacih/ jisghobbih ghalih innifsu.

Mario regret.IP.him repent.IP.him for.him his.self

'Mario is sorry for himself.'

Thus, the subject of impersonal verbs does show some subject properties: The unusualness of postverbal position, the possibility of zero case-marking, and the possibility of reflexive control. On the other hand, the experiencer of these verbs is even less subject-like than the 'have' possessor with respect to complementizer drop and imperatives. Like the 'have' possessor, it cannot be raised. $^{13}$ 


\section{A "personal" intransitive experiential verb}

Besides the somewhat unusual type of experiential verbs with a dative/accusative experiencer and an oblique stimulus (e.g. Latin taedet me alicujus rei 'something disgusts me'), many European languages more commonly show personal intransitive experiential verbs (e.g. Latin aliquid mihi placet 'something pleases me'), i.e. verbs that have a nominative/subject stimulus in addition to a dative experiencer. In Maltese, we have found only one verb so far which originally was of this type: sthaqqlu 'deserve', illustrated in (32). ${ }^{14}$

(32) Fija

Hija jisthoqqlu dan il-premju.

my.brother deserve.IP.to.him this the-prize

'My brother deserves this prize.'

The postverbal stimulus argument (here 'this prize') no longer behaves like a subject in this construction in that it never triggers subject-verb agreement. This is apparent from sentences like (33), where the stimulus argument is feminine, and where a feminine form like *tisthoqqlu would not be possible.

(33) Hija jisthoqqlu din il-karozza sabiha.

my.brother deserve.IP.to.him this the-car nice

'My brother deserves this nice car. (=This car is just right for my brother.)'

Furthermore, the stimulus may be a reflexive pronoun, as in (34) (this example is semantically odd, but syntactically it appears to be perfectly well-formed).

(34) Maria jisthoqqilha lilha nnifisha.

Maria deserve.IP.to.her to.her her.self

'Maria deserves herself.'

However, the stimulus argument does not behave like a normal direct object either, because a full-NP definite animate stimulus is not case marked. (By contrast, accusative case marking is obligatory with definite animate direct objects, as for instance in (16).)
(Lil) Diana jisthoqqilha
(*li-)r-ragel taghha.
(to) Diana deserve.IP.to.her (to)the-man of.her
'Diana deserves her husband.'

In other respects, this verb behaves just like the impersonal experiential verbs of $\S 3$, i.e. its experiencer is to some extent subject-like: (a) the verb shows obligatory agreement with the experiencer, i.e. forms like *sthaqq or *jisthoqq are impossible; (b) the experiencer is normally in preverbal position, and the stimulus in postverbal position; (c) the pronominal experiencer need not show any case-marking. 


\section{Transitive experiential verbs}

Constructions with transitive experiential verbs, i.e. verbs like those listed in (2), show even fewer subject properties than impersonal experiential verbs. Nevertheless, it is instructive to compare them to the other verbs that we have considered so far.

The major subject property that transitive-verb constructions have is the possibility of putting the experiencer in the preverbal position (with a resumptive pronominal direct-object suffix) as a normal option, as in (36b). However, the order stimulus-verb-experiencer, shown in (36a), is an equally normal option. In this respect, transitive experiential verbs differ from impersonal verbs, for which postverbal experiencers are quite unusual (cf. 22b-c), but also from normal transitive verbs, for which preverbal patients (though perfectly acceptable) are quite unusual (cf. $37 \mathrm{a}-\mathrm{b}$, where $37 \mathrm{~b}$ requires a special context; this is indicated by the symbol \#).

(36) a. Ir-rumanż il-g்did ta' Rushdie jinteressa lil Mario. the-novel the-new of Rushdie he.interest.IP to Mario 'Rushdie's new novel interests Mario.'

b. Lil Mario jinteressah ir-rumanż il-ġdid. to Mario he.interest.IP.him the-novel the-new 'Mario is interested in the new novel.'

(37) a. Mario qed jghin lil ommu.

Mario PROG he.help.IP to his.mother

'Mario is helping his mother.'

b. \#Lil ommu qed jghinha Mario.

to his.mother PROG he.help.IP.her Mario

'His mother is being helped by Mario.'

In addition, the preverbal experiencer may lack the case-marker lil in some special circumstances (again, this is marked by \#). In these verbs, there is no difference between full NPs and pronouns.

(38) a. Lil Anna / \#Anna iddisgustaha dan l-ikel.

to Anna Anna he.disgust.PF.her this the-food

'Anna is disgusted by this food.'

b. Lili / \#Jiena iddisgustani dan l-ikel.

to.me I he.disgust.PF.me this the-food

'I am disgusted by this food.'

Like impersonal experiential verbs, transitive experiencers cannot be raised (cf. 38 ), do not allow complementizer drop (cf. 40), and cannot be imperative addressees (*Joghigbok ir-rigal! 'Like the present!). ${ }^{15}$ 
(39) a. Irrid li joghgbok ir-rigal.

I.want.IP that he.please.IP.you the-present

(lit.) 'I want that you like the present (or: that the present please you).'

b. *Irridek joghgbok ir-rigal.

I.want.IP.you he.please.IP.you the-present

'I want you to like the present.'

(40) Lisa trid li/*ø joghgobha l-ktieb.

Lisa she.want.IP that/ $\varnothing$ he.please.IP.her the-book

'Lisa wants to like the book.'

Furthermore, transitive experiencers are even less subject-like than impersonal experiencers in that they cannot control reflexive pronouns, cf. (41b).

(41) a. Lisa toghgob lilha nnifisha.

Lisa she.please.IP to.her her.self

'Lisa (=stim.) pleases herself (=exp.); i.e. Lisa likes herself.'

b. *(Lil) Lisa toghgobha hija nnifisha. $(=12)$

to Lisa she. please.IP.her she her.self

'Lisa, she-self pleases her', i.e. 'Lisa likes herself.'

\section{An intermediate case}

In this section, we will briefly examine one verb that seems to be intermediate between the impersonal experiential verbs and the transitive experiential verbs, jidhirlu 'it seems to him, he is of the opinion'. An example is (42):

(42) Gorg u Mary jidhrilhom li x-xoghol tajjeb.

George and Mary seem.IP.to.them that the-work good

'George and Mary are of the opinion that the work is good.'

With respect to obligatory verb agreement, jidhirlu shows mixed behavior. A sentence like (43a) is not impossible, but it sounds less natural than (43b) or (42).

(43) a. ??Jidher lil Gorg u lil Mary li x-xoghol tajjeb. seem.IP to George and to Mary that the-work good 'George and Mary are of the opinion that the work is good.'

b. Jidhrilhom lil Gorg u lil Mary li x-xoghol tajjeb. seem.IP.to.them to George and to Mary that the-work good 'George and Mary are of the opinion that the work is good.'

Otherwise, this verb behaves much like the impersonal experiential verbs of $\S 3$. Thus, jidhirlu is possibly on its way to becoming a regular impersonal experiential verb, and its experiencer on its way to becoming a subject, but with this verb the process has only begun. 


\section{Conclusion and discussion}

To conclude this paper, in Table 1 we give the various subject properties that we examined in this paper.

\begin{tabular}{|c|c|c|c|c|c|c|}
\hline \multirow{9}{*}{$\begin{array}{l}\text { agreement in subject- } \\
\text { slot } \\
\text { raisability } \\
\text { imperative } \\
\text { zero-complementizer } \\
\text { with 'want' } \\
\text { reflexive control } \\
\text { agreement with verb } \\
\text { obligatory } \\
\text { zero case-marking on } \\
\text { pronoun possible } \\
\text { postverbal position } \\
\text { unusual }\end{array}$} & $\begin{array}{l}\text { habb } \\
\text { 'love' }\end{array}$ & $\begin{array}{l}\text { ghand- } u \\
\text { 'have' }\end{array}$ & $\begin{array}{c}\text { jiddispjacih } \\
\text { 'regret' } \\
\text { IMPERS. }\end{array}$ & $\begin{array}{l}\text { jidher } \\
\text { 'seem' }\end{array}$ & $\begin{array}{c}\text { joghgbu } \\
\text { 'like' } \\
\text { TRANS. }\end{array}$ & $(D O)$ \\
\hline & $\mathrm{Y}$ & $*$ & $*$ & $*$ & $*$ & $*$ \\
\hline & $Y$ & $*$ & $*$ & $*$ & $*$ & $*$ \\
\hline & $\mathrm{Y}$ & $\mathrm{Y}$ & $*$ & $*$ & $*$ & $*$ \\
\hline & $\mathrm{Y}$ & $Y$ & $*$ & $*$ & * & $*$ \\
\hline & $\mathrm{Y}$ & $\mathrm{Y}$ & $\mathrm{Y}$ & - & $*$ & $*$ \\
\hline & $\mathrm{Y}$ & $\mathrm{Y}$ & $\mathrm{Y}$ & $\mathrm{m}$ & $*$ & $*$ \\
\hline & $\mathrm{Y}$ & $Y$ & $\mathrm{Y}$ & $\mathrm{Y}$ & $\mathrm{m}$ & $*$ \\
\hline & $\mathrm{Y}$ & $\mathrm{Y}$ & $\mathrm{Y}$ & $\mathrm{m}$ & $\mathrm{m}$ & * \\
\hline $\begin{array}{r}\text { Tab } \\
(\mathrm{Y}=\mathrm{pr}\end{array}$ & $\begin{array}{l}\text { Subj } \\
t, \mathrm{~m}=\end{array}$ & $\begin{array}{l}\text { propertie } \\
\text { ixed, } *=\end{array}$ & $\begin{array}{l}\text { of experienc } \\
\text { ot present, - }\end{array}$ & $\begin{array}{l}\text { in Mal } \\
\text { loes not }\end{array}$ & $\begin{array}{l}\text { e } \\
\text { ply) }\end{array}$ & \\
\hline
\end{tabular}

As this table shows, the four groups of verbs which we examined show considerable variation in the behavior of their experiencer arguments. While the experiencer argument of a standard transitive verbs like $\hbar a b b$ 'love' show all of the subject-properties that we discussed, the possessor of ghandu/kellu 'have' shows only the majority, and the experiencer of impersonal and transitive experiential verbs only show a minority of subject properties. In the final column in Table 1, we included the direct object of normal transitive verbs, which has none of the subject properties.

We conclude that Maltese shows not only "object diffuseness" (Comrie \& Borg 1984), but also "subject diffuseness". This is not surprising - the process whereby experiencers are gradually grammaticalized to subjects is common cross-linguistically (Cole et al. 1980). Thus, the Maltese facts discussed here are just a particular manifestation of a widespread phenomenon.

We would not be surprised if similar results were obtained for other languages once their experiential verbs and the syntactic properties of their experiencers are studied from our perspective. The fact that Maltese has served for case studies of both object diffuseness (Comrie \& Borg 1984) and subject diffuseness (as in this paper) cannot, we think, be seen as evidence for a particular propensity for grammatical-relation diffuseness in this language.

Once a pattern such as that in Table 1 is established, the next question to ask is why the predicate types are arranged in precisely this way (i.e. $h a b b<$ 
ghand- $u<j i d d i s p j a c i h<j i d h e r<j o g h \dot{g} b u$, rather than, say, jiddispjacih $<$ habb $<$ ghand $-u<\ldots$ ), and why the subject properties are arranged precisely in this way, with agreement-marking and raisability being the most restrictive subject properties, and preverbal position being the most liberal subject property. An answer to this question presupposes at least some knowledge of the crosslinguistic picture. If we have data on only one language, it is always very difficult to tell language-particular historical accidents from significant patterns. For most of the features discussed here, we know of no cross-linguistic data, but Cole et al. (1980) make one important generalization concerning the subject properties of erstwhile non-subject experiencers: In diachronic change, experiencers usually acquire behavioral properties (such as control of reflexivization and omissibility) before they acquire coding properties (such as case marking and agreement). This does not help us much, because all of the properties discussed here fall in the category of behavioral properties, with one exception: The first property of Table 1 (agreement in subject slot) is a coding property, and as predicted by Cole et al., this property is among the latest to be affected by language change.

Finally, we should address the (perhaps somewhat philosophical) question in what sense the "subject properties" that we surveyed here are connected to the notion of "subject". An anonymous referee makes the following interesting comments:

It is being presupposed in this paper that subject is a cross-linguistically viable no-
tion, existing independently of what properties particular subjects have in particular
constructions in particular languages, and that there are properties which can only be
conceived of as properties of something else, viz. of subjects. However, as is being
shown, these so-called properties may well work in their own right, which suggests
that they themselves are the primary notions and 'subject' is a secondary notion that
is (or is not, as the case may be) definable in terms of patterns of these primaries.

We fully agree that the "subject properties" that we mentioned have their independent existence, and whether or not "subject" is a necessary notion in formal grammatical description is of course controversial (see Van Valin \& LaPolla 1997 for a comprehensive formal descriptive framework that has no place for this notion). Moreover, we are fully aware that "subject" cannot be an abstract (perhaps innate) notion that is somehow present in every language: As Dryer (1997) has shown, "subject properties" across languages are so diverse that it is not possible to find a set of core properties that subjects have in all languages. But while Dryer concludes from this that "subject" is not a cross-linguistically viable notion, this is not in fact a necessary conclusion. Following Croft's (2001) Radical Construction Grammar, we can say that there might be a functional definition of "subject" that represents the core of a typological prototype represented by the distributional patterns of a set of constructions across languages. Clearly there is a strong tendency for properties such as those in Table 1 to converge on a single argument type. As Croft points out, the problem is not 
the cross-linguistic definition of grammatical notions, but the languageparticular application of these notions. Thus, while we have little doubt what properties typically converge on a single argument type (cf. Keenan 1976 and much later work), it is quite doubtful, or at least highly framework-dependent, which Maltese arguments should be called "subjects". (Are the four subject properties of the experiencer of impersonal verbs sufficient to give them subject status? Any decision we take is arbitrary.) For this reason, we avoided a commitment to a particular formal synchronic description. Our terms "original subject" and "new subject" reflect the diachronic shift of subject properties from one argument type to another one. This has been the focus of our interest here.

\section{Appendix: The verb jismu 'be called'}

In the body of this paper we have limited ourselves to examining experiential verbs and pointing out subject-like behavior of their experiencer argument. The peculiarities of these verbs are of course due to the special meanings of their arguments: Experiencers are usually animate and stimuli inanimate, and this is why they tend to assimilate their behavior to agent subjects. But some nonexperiential verbs also show these properties, for instance $g h a n d u$, whose possessor argument has acquired subject properties (cf. §2).

Another special case that we would like to mention briefly here is the verb jismu 'be called', e.g. hija jismu Manwel 'my brother is called Manwel'. This may have started out originally as a transitive impersonal verb (**jisem hi-ja Manwel 'one calls my brother Manwel'), ${ }^{16}$ but the erstwhile direct-object argument (the Named) now occurs in preverbal position and shows a number of subject properties, just as in the case of impersonal experiential verbs (§3): Verb agreement with the Named is obligatory (*jisem is impossible), and, remarkably, case-marking on the new subject is impossible:
(44) * Lit-tfal
jisimhom
Mario u Rita.
to.the-children one.call.them Mario and Rita
'The children are called Mario and Rita.'

Thus, the Named argument is in a way more subject-like than the experiencer of impersonal verbs, but it is less subject-like than the possessor of ghandu 'have', e.g. in that complementizer drop in same-subject 'want' complements is not possible (contrast (45) with (8b) above).
(45) *Clelia trid
jisimha
Diana. (OK: Clelia trid li jisimha Diana.)
Clelia she.want.IP one.call.her Diana
'Clelia wants to be called Diana.'

If we included this non-experiential verb in Table 1, we would get a sixth type, intermediate between $g$ hand $u$ and impersonal experiential verbs, and the continuum-like nature of subject diffuseness would increase even further. 


\section{Addresses of the Authors}

Martin Haspelmath

Max-Planck-Institut für

evolutionäre Anthropologie

Inselstr. 22

D-04103 Leipzig (Germany)

e-mail: haspelmath@eva.mpg.de
Sandro Caruana

University of Pavia \& University of Malta

G.F. Abela Junior College

(Department of Italian)

G.Debono Square,

Msida, Malta

e-mail: scar2@um.edu.mt

\section{Notes}

* We are grateful to Joseph Brincat, Bernard Comrie, Bill Croft, Ray Fabri, Orin Gensler, and Paolo Ramat for useful comments on earlier versions of this paper.

1 The following abbreviations are used in interlinear glosses: DOBJ $=$ direct object, $\mathrm{IMPV}=$ imperative, $I P=$ Imperfect, NEG = negation, $\mathrm{PF}=$ Perfect, $\mathrm{PROG}=$ progressive, $\mathrm{SBJV}=$ subjunctive, $S G=$ singular, SUBJ $=$ subject.

2 Kellu is the suppletive past tense of $g$ handu.

3 The non-dislocated counterpart of (3a) at this pre-Maltese stage would have been:

(i) ghand Maria baqra

at Maria cow

'At Maria's place is a cow.'

4 The 3rd person singular masculine form of the Perfect serves as the citation form of verbs in Maltese.

5 The allomorphy in the 3rd person singular masculine $(-u$ vs. $-h)$ is purely phonologically conditioned: The suffix is $-u$ after consonants, $-h$ after vowels.

6 Note that in such irrealis subordinate clauses, the present tense based on ghand-is not possible with this verb, and the suppletive present tense ikollok must be chosen, which is based on the same root as the past tense kellu. This form is not normally used in indicative contexts: ikollok cannot mean 'you have'. However, it can be used in the modal sense 'you have to, you must', and in the future sense 'you will have' (as an abbreviation of the more regular se jkollok). Thus, Maltese has one verb that has a special future/subjunctive form, which came into being as an indirect result of the special present-tense form based on ghand- (cf. Haspelmath 1998 for this process).

7 However, it seems that while omission of $l i$ is preferred in (8a), non-omission is preferred in (8b).

8 Here are partial paradigms of 'regret' and 'open' that demonstrates the similarities (only the singular forms are given here). The suffixes are the same as those in $(5 \mathrm{~b})$ in $\S 1.3$.

$\begin{array}{lllll}\text { SG } 1 \text { jiddispjaci-ni } & \text { 'I regret' } & \text { jifthu-ni } & \text { 'they open me' } \\ 2 \text { jiddispjaci-k } & \text { 'you regret' } & \text { jifthu-k} & \text { 'they open you' } \\ & \text { 3M jiddispjaci- } h & \text { 'he regrets' } & \text { jifthu-h } & \text { 'they open him' } \\ \text { 3F jiddispjaci-ha } & \text { 'she regrets' } & \text { jifthu-ha } & \text { 'they open her' }\end{array}$

9 In impersonal verbs, our interlinear translations do not include a subject pronoun. Thus, although the verb in (14) is technically jiddispjacini [3SG.SUBJ-displease.IP-1SG.DOBJ], we gloss it simply as [displease.IP-me]. The gloss of course reflects the old syntactic structure, but this should not imply any claim about the synchronic syntactic analysis.

10 Again, it is instructive to compare two partial paradigms:

$\begin{array}{lllll}\text { SG } 1 \text { irnexxie-li } & \text { 'I managed' } & \text { fethu-li } & \text { 'they opened for me' } \\ 2 \text { irnexxie-lek } & \text { 'you managed' } & \text { fethu-lek } & \text { 'they opened for you' } \\ \text { 3M irnexxie-lu } & \text { 'he managed' } & \text { fethu-lu } & \text { 'they opened for him' } \\ \text { 3F irnexxie-lha } & \text { 'she managed' } & \text { fethu-lha } & \text { 'they opened for her' }\end{array}$


11 However, when the experiencer is 1st person singular, the form jisghobbi-ja ('I regret'), which is the regular outcome of jisg hob bi-ja, is still possible, alongside with the innovative form jisghobbi-ni, which shows morphological assimilation to verbs such as jiddispjaci-ni.

12 The form irnexxa of (19b) does exist, but it has a completely different syntax: It takes a nominative experiencer that agrees with the subject in the normal way, and it cannot be combined with a complement clause (thus: Mario irnexxa 'Mario was successful.')

13 One might be tempted to conclude that the grammaticalization from topic to subject has not advanced very far with these verbs: The only clear subject properties, reflexive control and preverbal position, could be argued to be really topic properties, and zero case-marking, too, is a property that non-subject topics have in Maltese, as we saw in (24).

14 Some speakers only allow a clausal complement with this verb, so that instead of (32) they would have:
(i) Hija
my.brother deserve.ip.to.him that he.have.ip the-prize
'My brother deserves to have the prize.'

15 Of course, many transitive experiential verbs allow the stimulus to be the imperative addressee when they have the causative reading (e.g. issorprendi lit-tifel 'Surprise the boy!'). This possibility is not relevant here, because experiencers can acquire subject properties only when the experiential verb has a non-causative meaning. Thus, we are not taking this reading of transitive experiential verbs into account.

16 The reason for thinking that the Named role was originally a direct object is the verbal morphology: The agreement suffixes are the same as the direct-object suffixes (cf. $5 \mathrm{~b}$ in $\$ 1.3$ ):

$\begin{array}{lll}\text { SG } & 1 & \text { jisimni } \\ & 2 & \text { jismek } \\ & \text { 3M } & \text { jismu } \\ & 3 \mathrm{~F} & \text { jisimha } \\ \text { PL } & 1 & \text { jisimna } \\ & 2 & \text { jisimkom } \\ & 3 & \text { jisimhom }\end{array}$

An intriguing possibility is that this verb arose from the noun isem 'name' by reanalysis. The original construction would have been Hija, ism-u Manwel, literally 'My brother, his name is Manwel'. Here ismu was somehow reanalyzed as a verb, and the possessive person-number suffixes were reanalyzed as direct-object suffixes. This hypothesis would explain why jismu lacks a past tense and an imperative form. Furthermore, as far as we know such a verb is not attested in Arabic, so it seems to be a Maltese innovation.

\section{References}

Belletti, Adriana \& Luigi Rizzi. 1988. "Psych-verbs and th-theory." Natural Language and Linguistic Theory 6.3, 291-352.

Borg, Albert \& Marie Azzopardi-Alexander. 1997. Maltese. (Routledge Descriptive Grammars) London: Routledge.

Bossong, Georg. 1998. "Le marquage de l'expérient dans les langues d'Europe”. In: Feuillet, Jack (ed.) Actance et valence dans les langues de l'Europe. Berlin: Mouton de Gruyter, 259-294.

Cole, Peter, Wayne Harbert, Gabriella Hermon \& S.N. Sridhar. 1980. "The acquisition of subjecthood." Language 56, 719-743.

Comrie, Bernard. 1982. "Syntactic-morphological discrepancies in Maltese sentence structure." Communication \& Cognition 15.3/4, 281-306.

Comrie, Bernard. 1989. Language universals and linguistic typology. Oxford: Blackwell.

Comrie, Bernard \& Albert Borg. 1984. "Object diffuseness in Maltese". In: Frans Plank (ed.), Objects: Towards a theory of grammatical relations. New York: Academic Press.

Croft, William. 1993. "Case marking and the semantics of mental verbs." In: James Pustejovsky (ed.), Semantics and the Lexicon. Dordrecht: Kluwer Academic, 55-72. 
Croft, William. 2001. Radical construction grammar: syntactic theory in typological perspective. Oxford: Oxford University Press.

Aikhenvald, Alexandra, R.M.W. Dixon \& Masayuki Onishi (eds.). 2001. Non-canonically marked subjects and objects. Amsterdam: Benjamins.

Dryer, Matthew. 1997. “Are grammatical relations universal?" In: Joan Bybee, John Haiman \& Sandra A. Thompson (eds.), Essays on language function and language type. Amsterdam: Benjamins, 115-143.

Fabri, Ray. 1993. Kongruenz und die Grammatik des Maltesischen. Tübingen: Niemeyer.

Haspelmath, Martin. 1998. "The semantic development of old presents: new futures and subjunctives without grammaticalization". Diachronica 15.1, 29-62.

Keenan, Edward. 1976. "Toward a universal definition of 'subject'." In: Charles N. Li (ed.), Subject and topic. New York: Academic Press, 303-333.

Pesetsky, David. 1995. Zero syntax: experiencers and cascades. Cambridge, MA: MIT Press.

Reh, Mechthild (ed.) 1998. Experienskonstruktionen in afrikanischen Sprachen. Hamburg: Universität Hamburg, Institut für Afrikanistik.

Stassen, Leon. 2001. "Predicative possession." In: Martin Haspelmath et al. (eds.), Language typology and language universals: An international handbook. Berlin: Mouton de Gruyter, 954-960.

Van Valin, Robert D. \& Randy LaPolla. 1997. Syntax: Structure, meaning and function. Cambridge: Cambridge University Press. 
Bereitgestellt von | Universitaetsbibliothek Leipzig Angemeldet

Heruntergeladen am | 09.05.16 12:03 